\title{
Ripping the Scab off in the Authorial and Authoritative \\ Narratives of Racial Oppression \\ In Morrison's Home
}

\author{
Ahmed M. AL-Kahky* \\ aalkahk@yahoo.com
}

\begin{abstract}
The unrevealed secrets of America's desegregated army in the Korean War, the racial medical experimentations and the racial oppression against African Americans-involving austere rules of segregation and acts of horrific violence - are all exposed through narrative discourse in Toni Morrison's tenth novel, Home. The aim of this paper is to investigate how Morrison makes use of dialogic narrative focalizing viewpoints in order to deconstruct the monologic authoritative narrative of the 1950s. By giving the main character great liberty to question her implied authorial voice, Morrison opens the door to the deconstruction of the unquestionable ideologies and gives narrative agency to the subaltern maimed voices in American history. Morrison applies a dialogic narrative technique that aims at questioning the authoritative narrative discourse of America in the 1950s through questioning her implied authorial narrative voice.
\end{abstract}

Key Words: Authorial narrative- Authoritative narrativeViolence- PTSD- Korean War- Racial Medicine- Raciam.

\footnotetext{
*Associate Professor- Department of English Language and Literature Faculty of Arts- Damietta University.
}

(Ripping the Scab off in the Authorial ...)Dr. Ahmed AL-Kahky 
Toni Morrison's tenth novel, Home (2012), recounts the story of the odyssean homecoming of Frank Money, a black Korean-war veteran, to his hometown in Georgia in order to resuscitate his lost identity; rather, his manhood and psychological balance. Still, in spite of the novel's brevity for which Morrison has been criticized, critical appraisal has unanimously focused attention on its depth. Thus, in her interview with Morrison, in "Toni Morrison: I Want to Feel What I Feel. Even If It's Not Happiness," Emma Brockes writes that like her earlier novels Home's "slim spine belies a fertile narrative imbued with and embellished by Morrison's visionary scope and poetic justice." (n.p.) Likewise, Blayze Hembree wonders in "Home by Toni Morrison" how does Morrison's "Stripped-bare" novel continue to "offer a complex perspective of the black experience?"(n.p.) Heller Mcalpin also sheds light on the complex nature of this novel in '“Home': Toni Morrison's Taut, Triumphant New Novel" that this novel is "accessible, tightly composed and visceral as anything Morrison has written." However, this critical acclaim of the novel's depth is explicable in light of its exquisitely innovative narrative technique and iconoclastic re-presentation of the 1950s America. It is through the narrative of the post-war traumatized experience of its main character Frank Money that Morrison rewrites the 1950s in the "American imagination" as Erin Penner explains, in "For Those

(Ripping the Scab off in the Authorial ...)Dr. Ahmed AL-Kahky 
"Who Could Not Bear to Look Directly at the Slaughter": Morrison's Home and the Novels of Faulkner and Woolf.":

[Morrison] uses her novel to explore how a narrative of the 1950s framed as a golden era contributes to the neglect of soldiers returning from "The Forgotten War" and to the increasing despair of individuals pressured to take the blame for what are deeply entrenched — but ignored-social ills (343).

The aim of this paper is to investigate how Morrison makes use of dialogic narrative focalizing viewpoints in order to deconstruct the monologic authoritative narrative of the 1950s. By giving the main character great liberty to question her implied authorial voice, Morrison opens the door to the deconstruction of the unquestionable ideologies and gives narrative agency to the subaltern maimed voices in American history. Within the theoretical framework of Bakhin's dialogism, the present study hypothesizes that Morrison applies a dialogic narrative technique that aims at questioning the authoritative narrative discourse of America in the 1950s through questioning her implied authorial narrative voice.

Mikhail Bakhtin writes in The Dialogic Imagination that the "authoritative word" of the hegemonic culture is "acknowledged in the past," and hierarchically distanced from any other discourse because it is sacredly non negotiable. This authoritative voice, according to Bakhtin hegemonies even our "verbal consciousness" (343) in such a manner as people under its sway are not given any options but either to affirm it or totally

(Ripping the Scab off in the Authorial ...)Dr. Ahmed AL-Kahky 
reject it. Nonetheless, in an interview for USA Today on May 8, 2012, Morrison said that her aim in writing a novel that deals with 1950s America was to "rip the scab off that period" (n.p.) In fact, the 1950s have always been presented in the hegemonic authoritative account of the American national history as a romanticized golden decade; nevertheless, Morrison has an opposing viewpoint. In "Toni Morrison on 'Home"” Lisa Shea quotes Morrison speaking about her novel as an attempt to expose the hidden facts about the mid-twentieth-century America:

I was interested in the 1950 s because we associate it with the postwar Doris Day decade, when it really wasn't like that. Forty thousand Americans died in the Korean War, which wasn't called a war-it was called a police action. It was the time of the McCarthy hearings and a lot of medical apartheid, the license of [eugenics practitioners] preying on black women, the syphilis trials on black men. (n.p.)

Thus, in spite of its brevity, Home tackles a plethora of themes that mainly pertain to the unspoken-of racial segregation and social injustice practiced against Afro-Americans in the middle of the twentieth century. In addition, Home involves innovative narrative strategies; such as, the contending narratives of the first and the third person narrators and the recounting of the same events from conflicting narrative stands. The reader's role in this narrative paradigm is not merely to piece together the details of the story as understood from the contention between the

(Ripping the Scab off in the Authorial ...)Dr. Ahmed AL-Kahky 
narrators, but also to try to find out the truth within the discrepancies and accusations of skipping facts or hiding them. These narrative techniques are aimed at deconstructing the authorial as well as authoritative agencies that falsified the facts of the Korean War abroad and the facts of the debilitated status of the blacks at home in 1950s America.

In “An Interview with Toni Morrison," Morrison tells Francois Noudelmann that "so much of our history has been erased, distorted, and reconstructed to a level of fantasy. It's as though avoiding the truth of the past is somehow so degrading that no one can function" (37). Therefore, Toni Morrison's use of contending multiple narrative voices in Home aims at criticizing the dominant cultural authoritative narrative that has hidden the historical facts of the Korean War and of the acts of racism against blacks in 1950s. This authorial endeavor on part of Morrison can be traced back to her earlier lectures in 1996 as she clearly expresses her viewpoint of the need to reveal the facts of that period:

Political language is dominated by glorifications of some past decade, summoning strength from the pasted-on glamour of the twenties - a decade rife with war and the mutilation of third world countries; from attaching simplicity and rural calm to the thirties - a decade of economic depression, worldwide strikes and want so universal it hardly bears coherent thought; from the righteous forties when the "good war" was won and millions upon

(Ripping the Scab off in the Authorial ...)Dr. Ahmed AL-Kahky 
millions of innocent died wondering, perhaps what that word, good, could possibly mean (175).

Thus, the challenge against the authorial voice is a means of subverting the dominant authoritative voice and questioning its agency. The first chapter of Home is typed in italics as well as all the intersecting chapters in which Frank Money, the novel's main character, speaks as the novel's first person narrator. Frank directs his speech towards a third person narrator-an implied authorwhose narrative accounts he permanently doubts. The scene is set in Lotus, Georgia, Frank Money's hometown, which he describes as the "worst place in the world, worse than any other battlefield" (83). Frank recounts how he and his little sister crawled through "a crawl space that some animal had dug-a coyote maybe, or a coon dog" (3) into a farmland outside Lotus where they witnessed the burial of a black man who, later on the reader learns, was killed by his own son in a lynch fight just for the murderous joy of some white men:

We saw them pull a body from a wheelbarrow and throw it into a hole already waiting. One foot stuck up over the edge and quivered, as though it could get out, as though with a little effort it could break through the dirt being shoveled in. we could not see the faces of the men doing the burying, only their trousers; but we saw the edge of a spade drive the jerking foot down to join the rest of itself (Home 4).

(Ripping the Scab off in the Authorial ...)Dr. Ahmed AL-Kahky 
The memory of the burying this lynch victim assumes no less importance than the memory of the image of the killers' horses that "rose up like men. We saw them. Like men they stood" (3). The first symbolizes the humiliating burial of human dignity in Afro-Americans at the hand of unjust racist white men and the latter symbolizes the vain pretense of virility which assumes focal interest in Frank Money's psychological balance. The homecoming journey is in fact for the purpose of healing the traumatic wounds inflicted upon Frank Money's human dignity and manhood. Still, the first chapter of the novel ends with Frank Money's launching the first of a series of skeptic attacks against the authorial voice of the third person narrator; therefore, deeming it unreliable. Though Frank neither forgets the burial nor the horses, he says, “Since you're set on telling my story, whatever you think and whatever you write down, know this: I really forgot about the burial. I only remembered the horses. They were so beautiful. So brutal. They stood like men" (Home 5).

In fact, the burial of the lynch victim is not the only burial that haunts Frank Money's memory, but also the burial of an "elderly man named Crawford" whom he remembers twenty years ago sitting on "his porch steps and [refusing] to vacate" when orders were given to the residents of the fifteen houses of the little community, where he lived with his family at the age of four, to "leave their little neighborhood on the edge of town. Twenty-four hours, they were told, or else. "Else" meaning "die"" (10).

(Ripping the Scab off in the Authorial ...)Dr. Ahmed AL-Kahky 
Crawford who refused to leave his home was brutally killed: "[B]eaten to death with pipes and rifle butts and tied to the oldest magnolia tree in the country - the one that grew in his own yard" (Home 10).

Frank has his free independent voice that is empowered capacity daring enough to question the authorial voice and even to challenge it to reveal all the hidden facts. So he says that the author can neither imagine nor describe how horrible the memory of the forced displacement was. He says, "You don't know what heat is until you cross the border from Texas to Louisiana in the summer. You can't come up with words that catch it. Trees give up. Turtles cook in their shells. Describe that if you know how" (Home 41).

Thus, through this narrative of the vicious practices of racism, lynching and forced displacement, Morrison introduces the reader to the unspoken-of realities of 1950s. In America as a Civilization, Max Lerner sheds light on the facts concerning the unjust prosecution system that used double standards in judging the crimes done by blacks and those done by whites:

White supremacy in the South has always used lynching as the ultimate sanction against the defilement of white blood. While these lynchings have steadily decreased [...], the Southern courts have operated on a double standard of justice in applying the laws against rape: most of the prosecutions are against Negroes, and even where whites are brought to

(Ripping the Scab off in the Authorial ...)Dr. Ahmed AL-Kahky 
trial they are not given the death penalty that is visited upon the Negroes (521).

There is repetitive oscillation between the first and the third narrative voices which sometimes makes use of the stream of consciousness technique through which the reader is intended to get engaged in piecing together Frank Money's traumatic memories of war, forced displacement, lynch fighting, and police brutality. To begin with, the reader learns that everything reminded Frank of "something loaded with pain" (Home 8). Frank begins his homecoming journey as soon as he receives a letter summoning him to rescue his sister with a warning note: "come fast. She be dead if you tarry." The authorial narrative discourse also reveals another fact about the exploitation the black PTSD war veterans whose dead bodies were sold off for experimentation at medical schools. Taking refuge at the nearby parsonage of AME Zion, Reverend Locke tells Frank that he must be lucky for being able to escape from the hospital because his body would have been sold for medical experiments. Reverend Locke tells Frank, "Well, you know, doctors need to work on the dead poor so they can help the live rich" (Home 12). In the mental asylum Frank Money, seemingly like some other war veterans, is kept by force in handcuffs and is given regular doses of morphine. At 2:00 a.m. Frank is faking a semi-coma in order to avoid being given another "immobilizing" shot of morphine. It is remarkable

(Ripping the Scab off in the Authorial ...)Dr. Ahmed AL-Kahky 
how Frank equates between his attempts at survival in the battlefield and his attempts at survival in the hospital. Thus, the war veteran has not come home yet as it seems that his fight for survival and personal safety still continues in his home country. It is remarkable how Frank's battle is not over either abroad or at home: his fight is for survival against foreign and home enemies.

Through the narrative of Frank's escape, the reader becomes aware of the dangers of being an aimless and barefooted black person strolling the streets at midnight "Walking anywhere in winter without shoes would guarantee his being arrested and back in the ward until he could be sentenced for vagrancy... being barefoot would contradict "purposefulness" and standing still could prompt a complaint of "loitering". However, the memory of Frank's shoeless escape evokes another memory of his forced evacuation at the age of four along with the neighborhood of his black community. In fact, black people were oppressed by the whites who could imprison, evacuate, or kill them for whichever reason. Frank says, "You could be inside, living in your own house for years, and still, men with or without badges but always with guns could force you, your family, your neighbors to pack up and move with or without shoes" (Home 9).

Moreover, through this narrative, the problems that faced the blacks in 1950s are exposed; such as, the participation of black soldiers in a desegregated army in the Korean War and their return to a disintegrated country that mistreated them because of

(Ripping the Scab off in the Authorial ...)Dr. Ahmed AL-Kahky 
its racial prejudice. Reverend Locke gives voice to this idea as he tells Frank "An integrated army is integrated misery. You all go fight, come back, they treat you like dogs. Change that. They treat dogs better" (18). In The American Dilemma in Uniform: Race in the Armed Forces Charles C. Moskos, Jr. comments on what he labels "America's perennial dilemma-race" (94). Moskos refers to the historical fact that President Truman's Desegregation Order in 1948 was designed by a committee that was set up for the purpose of implementing equal "treatment and opportunity for armed forces personnel." Still, in 1950 the Korean War was the main impetus for increasing the number of black soldier fighting in the same regiments along with whites:

The Korean conflict was the coup de grace for segregation in the army. Manpower requirements in the field for combat soldiers resulted in many instances of ad hoc integration... As integration in Korea became more standard, observers consistently noted that the fighting qualities of blacks differed little from those of whites. This contrasted with the blemished record of the all-Negro Twenty-fourth Infantry Regiment. (Moskos 97).

Nevertheless, Frank a black PTSD (Post Traumatic Stress Disorder) war veteran has his umbilical relationship with the author, in Bakhtinian terms, severed clean. He is given a free independent voice that is capable of questioning his fictional creator and in a daring manner to reveal the facts of his experience. So, Frank bitterly addresses his fictional creator

(Ripping the Scab off in the Authorial ...)Dr. Ahmed AL-Kahky 
saying, "Talk about tired. Talk about hungry. I have eaten trash in jail, Korea, hospitals, at table, and from certain garbage cans. Nothing, however, compares to the leftovers at food pantries. Write about that, why don't you!' (Home40). Moreover, the home-coming black veterans were racially prejudiced against and oppressively abused in myriad ways such as the infamous acts of the police brutality and the racist medical treatment. Maxine L. Montgomery explicates the ironic situation of Frank Money as a war veteran who fights for America and when he returns back he faces racial oppression in Re-Membering the Forgotten War: Memory, History, and the Body in Toni Morrison 's "Home":

It is during the Korean War that blacks fought alongside whites in an integrated military arrangement. Despite the façade of racial harmony, returning black soldiers face continued oppression on American soil. Callousness from the doctors at the veteran hospital in Chicago where Money undergoes treatment for Post-Traumatic Stress Disorder furthers his sense of alienation (321).

There is, in addition, a definite inter-textual reference to Virginia Woolf's Mrs. Dalloway in which the victim of PTSD Septimus had felt that "some horror had come almost to the surface and was about to burst into flames, terrified him" upon hearing a car backfiring - something that kept him mesmerized and "rooted to the pavement" (18). Similarly, Frank Money in Morrison's Home is a PTSD victim who wonders if he had "thrown himself on the ground at the sudden sound of backfire?" or what else was the

(Ripping the Scab off in the Authorial ...)Dr. Ahmed AL-Kahky 
cause that the police arrested him, "What indeed. Other than that B-29 roar, exactly what he was doing to attract police attention was long gone... "I must have been acting up," he said. "Something like that." He Truly could not remember" (15). Erin Penner remarks further that Morrison echoes the experience of Woolf's war veteran who sees his friends getting killed then returns to an indifferent society. Contrastively, in both novels the ailments of the PTSD veterans assume the focal point of narrative interest in order to expose the unspoken of realities of the war:

Rather than allowing postwar peace to dominate popular representations of the 1950s, she shows Frank using the instincts of the war front at the hospital, on public transportation, and in most situations in which racial conflict might arise. Unlike Septimus, for whom shell shock explains his struggles to disentangle the war front from London, Frank's continued use of warfare imagery reflects the conditions of the world that greets him upon his return to the United States (347).

Same as in Mrs. Dalloway, Lucrezia Smith (Rezia) has to bear with Septimus' post traumatic disorder as Lillian Florence Jones in Home has to withstand Frank Money's post traumatic disorder. Lillian begins living with Frank in her tiny apartment after a short courtship in the laundry where she works. However, Frank proves himself impossible to cope with her love of life and diligent struggle to live her American dream. Thus, breaking up with Frank was Lillian's biggest relief because she was "minus the 
burden of shouldering a tilted man" (Home 80). She resented how in vain she tried to disregard his unpredictable neurotic erupts of violent behavior and his mortifying idleness. Breaking up with Frank relieved Lillian from those unnerving "multiple times when she came home to find him idle again, just sitting on the sofa staring at the rug" (Home 79).

Ripping "the scab off" that period, as Morrison says about her novel, the third person narrative voice of Frank's homecoming serves to expose the oppressive practices of racial prejudice against the blacks. For instance, Frank has to be extra cautious about his movements in the city because of the danger of being caught by the white policemen who suspect any black person. He has to keep a list of some "addresses and names of rooming houses, hotels where he would not be turned away" (23). As a member of the segregated black race, Frank Money is denied some simple rights such as using a bathroom in a public station. $\mathrm{He}$ "wanted to get into the bathroom, pee, and look in the mirror to see if he had an eye infection, but the sign on the door stopped him. He relieved himself in the shrubbery behind the station, annoyed and a little frightened by the colorless landscape" (Home 24-25). On the train Frank enters a passenger car and "pushes through the separation green curtain" used in those days to segregate blacks from whites on public means of transportation. Lerner shows further, though in brief manner, how the laws of 
segregation were strictly practiced against blacks especially in the south during that period:

No Negro is the South could break the laws and traditions of segregation when he went to work on a bus, or wanted to eat lunch or dinner in a restaurant, when he tried to travel on a train, when he wanted to see a movie or a play. In most Southern cities no Negro would dare park his car in front of the post office without running the risk of being considered "an uppity nigger," nor would he dare walk late at night in the white section of the town. (519).

In Home, Toni Morrison gives another glimpse of the atrocities of the segregation practices against the blacks through the narrative of Frank Money's journey back to his southern hometown. On the train Frank encounters a black couple who were harshly beaten for trying to buy coffee from a coffeehouse that does not allow blacks in. The angry white mob beats the husband and breaks his wife's nose as she tries to rescue him. In fact, "[t]he owner or customers or both knocked him out. Actually, put their feet in his butt and knocked him down, kicked some more, and when his lady came to help, she got a rock thrown in her face" (Home 25). Frank finds the husband seething with anger and his "face a skull of shame and its partner, rigid anger" (Home 24). Frank, a typical victim of racial oppression feels empathetic for the man whom he imagines would later beat his wife because of

(Ripping the Scab off in the Authorial ...)Dr. Ahmed AL-Kahky 
the shame he felt for being beaten in front of her eyes in spite of her vain effort to rescue him. It is a humiliation of manhood that echoes Frank's already crushed one, the implied authorial voice in Home presumes:

The abused couple whispered to each other, she softly, pleadingly, he with urgency. He will beat her when they get home, thought Frank. And who wouldn't? It's one thing to be publicly humiliated. A man could move on from that. What was intolerable was the witness of a woman, a wife, who not only saw it, but had dared to try to rescuerescue!- him. He couldn't protect himself and he couldn't protect her either, as the rock in her face proved. She would have to pay for that broken nose (Home 26).

It is noteworthy that the authorial narrative voice assumes that the man feels ashamed for being beaten in front of his wife. This narrative voice also suggests that the man is going to vent his negative feelings of anger and shame on his wife as soon as they go home. However, Frank Money's free independent voice refutes all that was presumed by the narrative voice.

Likewise, within this narrative of Frank's journey to his hometown, police brutality against blacks is given its worst representation in the story of the little black boy, Thomas, who was shot by a cop and left with a permanently deformed arm. Frank is offered the courtesy of sleeping a transient night at the house of the boy's parents. In relation to the theme of Frank's shuttered sense of manhood, Thomas's father, Billy, introduces

(Ripping the Scab off in the Authorial ...)Dr. Ahmed AL-Kahky 
his son to Frank as "our little man Thomas," whose right arm is, Frank notices, "sagging at his side" (Home 30). Billy tells Frank how Thomas the eight-year kid was shot by "some redneck rookie [who] thought his dick was underappreciated by his brother cops," because Thomas was playfully aiming his cap pistol at the police while running up and down the sidewalk. It is remarkable, though, how Billy sardonically says that the police "who shoot anything they want" did Thomas a favor as they kept him off the street, so now he is a "math whiz. Wins competitions all over. Scholarships pouring in" (Home 31). Still, when Frank asks the little boy what he wants to be when he grows up, he simply tells him that he wants to become a "man" (33). This wish for the achievement of manhood on part of the little boy resonates with Frank Money's wish to recuperate his own manhood.

In fact, Morrison's blurring of the borderline between her implied authorial narrative voice and the first person narrative voice of Frank Money aims at involving the reader in the process of narration - not as a passive receptacle but as active seeker of truth - as the line between fiction and reality is blurred. Frank's narrative voice constantly doubts Morrison's implied authorial one and even questions its credibility. It is remarkable how the narrative discourse in Home is divided between the third person narrative point of view, which assumes a reporting narrative stance, and the stance of the argumentative first person narrative

(Ripping the Scab off in the Authorial ...)Dr. Ahmed AL-Kahky 
point of view-usually typed in italics. Thus, in chapter five, Frank says:

Earlier you wrote about how sure I was that the beat-up man on the train to Chicago would turn around when they got home and whip the wife who tried to help him. Not true. I didn't think any such thing. What I thought was that he was proud of her but didn't want to show how proud he was to the other men on the train. I don't think you know much about love. Or me (Home 69).

Similarly, Frank says that his hometown Lotus Georgia is "the worst place in the world, worse than any other battlefield," (Home 83) then, he challengingly doubts the accuracy of the authorial narrative voice as he says, "You never lived there so you don't know what it was like...Don 't paint me as some enthusiastic hero" (Home 84). In fact, Morrison allows for the disturbance of the typical roles of the character and the narrator with the emphasis on the idea that neither voice presents the finite truth. Consequently, the reader is urged to reconsider his status as a passive receptacle of the hegemonic authoritative account of 1950s' romanticized Civil Rights movement, and the Korean War, which is usually described in the historical authoritative discourse as a mere "police act." Ralph Pordzik writes, in Nationalism, Cross-Culturalism, and Utopian Vision in South African Utopian and Dystopian Writing 1972-92, that Toni Morrison's narrative discourse includes 'mutually exclusive

(Ripping the Scab off in the Authorial ...)Dr. Ahmed AL-Kahky 
versions of history [which] are implicitly placed in confrontation in order to stress the fact that the past is not a set of established truths in which all further developments originate, but rather a contested site of cultural codes, each designed to preserve (or efface) a particular version of cultural and national identity" (180181). Morrison's artistic ingenuity prevails her exposition of the falsified nostalgic image of the 1950s prevalent in the American authoritative discourse. Penner writes that Morrison is "overtly critical of the popular perception of the 1950s": of how the systematic presentation of nostalgic American past lead the Americans to ignore the systematic racism of the era. This American nostalgia also led to the "disregard of the brokenness of servicemen who returned from war only to find America impatient to characterize itself as a society of peace and progress (350).

This is per se the role dialogic fictional narrative should assume in questioning the authoritative hegemony over political and historical discourses as Mikhail Bakhtin theorizes in his essays on dialogic imagination. According to Bakhtin's theory of dialogism, the author of a dialogic narrative intends to communicate a certain ideological stance; still, his narrator(s) does not become a passive receptacle of his ideology. This is due to the dialogic principle that the fictional character/narrator is independently free to express his ideology independently from the author as Bakhtin explicates that the character, in a dialogic novel,

(Ripping the Scab off in the Authorial ...)Dr. Ahmed AL-Kahky 
is 'treated as ideologically authoritative and independent; he is perceived as the author of a fully weighted ideological conception of his own[...] as if the character were not an object of authorial discourse, but rather a fully valid, autonomous carrier of his own individual word" (Bakhtin, 5). In Morrison's Home the hero Frank Money has his independent self-consciousness of which he is duly aware; therefore, he is capable of questioning, contending and correcting the authorial narrative. In fact, this fits in Bakhtin's idea of the total independence of the fictional hero from his creator as he writes "If the umbilical cord uniting the hero to his creator is not cut, then what we have is not a work of art but a personal document" (51). In Toni Morrison's Home, the narrative discourse allows for the dialogic reciprocal interaction between independent narrative voices. In this dialogic milieu, the first person narrative voice of the main character and the third person narrative voice of the implied author are placed alongside the narrative discourse of authoritative national history. As consequence, the unspoken of, and/or forgotten, facts are shown in a new light and, in dialogic terms, given voice. Thus, Morrison deconstructs the authoritative discourse by questioning its voice and raising doubts about its integrity. This authorial endeavor, in Bakhtinian terms, aims at disempowering the authoritative "word," which "demands that we acknowledge it, that we make it our own; it binds us, quite independent of any power it might have to persuade us internally" because it is "located in a

(Ripping the Scab off in the Authorial ...)Dr. Ahmed AL-Kahky 
distanced zone, organically connected with a past that is felt to be hierarchically higher" (Bakhtin, 342).

In Playing in the Dark: Whiteness and the Literary Imagination, Toni Morrison deals extensively with the idea of how the hegemonic "Eurocentric learning" has an "entire range of views, assumptions, readings, and misreading" (7) pertaining the unrecognition of the existence of the African-Americans in the general cultural awareness of the American literary circles, or what she philosophically labels "knowledge." Therefore, Morrison writes:

[...] such knowledge assumes that the characteristics of our national literature emanate from a particular "Americaness" that is separated from and unaccountable to this presence. There seems to be a more or less tacit agreement among literary scholars that, because American literature has been clearly the pressure of white male view, genius, and power, that views, and power are without relationship to and removed from the overwhelming presence of black people in the United Sates (4-5).

This Americaness manipulates a higher loftier sphere that excludes the presence of the American-Africaness and denies it the right of self-expression by always muting its voice in the national American culture. So, according to Bakhtinian dialogism, this superior hegemonic Americaness is "is given (it sounds) in lofty spheres, not those of familiar contact. Its language is a

(Ripping the Scab off in the Authorial ...)Dr. Ahmed AL-Kahky 
special (as it were, hieratic) language. It can be profaned. It is akin to taboo. i.e., a name that must not be taken in vain" (342). Moreover, according to Bakhtin's viewpoint, this Americaness is a kind of an authoritative discourse that:

[P] ermits no play with the context framing it, no play with its borders, no gradual and flexible transitions, no spontaneously creative stylizing variants on it. It enters our verbal consciousness as a compact and indivisible mass; one must either totally affirm it, or totally reject it (343).

Morrison chose to write against the hegemonic monologicality of authoritative American cultural discourse-whether in political terms or in fictional creation - by advocating for the creation of a polarity of dialogic voices in mutually dialogic interaction, as Toni Morrison laments the racist exclusion of the African voice by the hegemonic authoritative American culture. In this cultural paradigm, Morrison explicates, the Afro-American is allowed a coded denotative and cognitive voice that only asserts the egocentricity and supremacy of the white cultural hegemony:

Here, in this nexus, with its particular formulations, and in the absence of real knowledge or openminded inquiry about the African and AfricanAmericans, under the pressures of ideological and imperialistic rationales for subjugation, an American brand of Africanism emerged: strongly urged, thoroughly serviceable, companionably egoenforcing, and pervasive. For excellent reasons of state-because European sources of cultural hegemony were dispersed but not yet valorized in

(Ripping the Scab off in the Authorial ...)Dr. Ahmed AL-Kahky 
the new country - the process of organizing American coherence through a distancing of Africanism became the operative mode of a new cultural hegemony (8).

For instance, Frank the main character in Morrison's Home is a black PTSD veteran of the Korean War who does not want to go back to his hometown without his two best friends whom he saw getting killed in combat. He remorsefully thought that he was "far too alive to stand before Mike's folks or Stuff's. His easy breath and unscathed self would be an insult to them" (Home 15). Still, we learn, through the authorial narrative voice, that Frank suffered like so many other black young men from being marginalized in a society that does not bear their mere existence except in terms of slavery and subalternation. Frank-with both "parents dead, one of lung disease, another of a stroke" (Home 34) - thought along with his two friends that "the army was the only solution. Lotus [their segregated hometown] was suffocating, killing him and his two best friends" (Home 35). Lotus was a desperate black community depraved, like many other racially segregated communities, of any environmental advantages. The narrative discourse is replete with references to the depravation of any ecological, medical, educational or occupational opportunities. So lotus was "separate, with no sidewalks or indoor plumbing, just fifty or so houses and two churches," (Home 46)

(Ripping the Scab off in the Authorial ...)Dr. Ahmed AL-Kahky 
and Frank and his friends thought that the Army was their only chance to leave those mortifying conditions.

In fact, historical records show that racial segregation was a wide-spread policy in the United States that prohibited people of color, who belonged to whichever ethnicity other than the white Americans, to rent or buy residence in certain restricted areas. So, Morrison makes reference to those historical facts in her fictional account of Frank Money's relationship with his girlfriend Lillian Florence Jones. Lillian is an African American woman trying to earn her living in spite of the harshness of the prevalent American segregation laws and racial prohibitions. She is a self-dependent woman who provides for herself by taking menial jobs such as a cleaning woman, a seamstress in a theater and a laundry assistant. In spite of the fact that Lillian is a hard working woman filled with determination to fulfill her American dream, she is denied any self-developing opportunities such as owning a house of her own. In fact, there were restrictive laws against allowing black people to rent houses in certain areas. For instance, Lillian is prevented from buying an apartment in a certain area that's only restricted to the whites:

The agent dropped her eyes, then decided not to lie. 'Well, no, but there are restrictions.'[...] No part of said property hereby conveyed shall be used or occupied by any Hebrew or by any person of the Ethiopian, Malay or Asiatic race expecting only employees in domestic service (Home 73).

(Ripping the Scab off in the Authorial ...)Dr. Ahmed AL-Kahky 
It is also noteworthy how Morrison makes use of some minor characters such as Lillian Jones to tackle American antiCommunism through the official practices of what is notoriously referred to as McCarthyism. The term was first used in reference to U.S. Senator Joseph McCarthy who announced in a public speech an alleged list of a communist party working secretively in the State Department. McCarthyism was later used in a broader sense in mass media, and as part of U.S. anti-Communist propaganda of the $1950 \mathrm{~s}$, to refer to the practice of unproved accusations of belonging to, or even sympathizing with, the antagonistic Communist party. Lillian in Home is a representative character of the effect of McCarthyism on the mainstream American public. She is resentful of losing her chance to get a career shift with some financial advancement as a seamstress in Mr. Stone's theater when he gets arrested for showing a play that promotes Communist ideas.

There is also another reference to McCarthyism that comes through the minor character of Dr. Beau's assistant, whom he dismisses immediately after realizing his communist sympathies. Thus, though the assistant was young and friendly, Dr. Beau dismisses him because he 'wouldn't have fellow travelers in his house" (62). Commenting on the chaotic atmosphere of chauvinistic nature of false accusations, Max Lerner elaborates, "This was the American mood in the inquisitional years of the early 1950 s that came to be called the era of "McCarthyism" after

(Ripping the Scab off in the Authorial ...)Dr. Ahmed AL-Kahky 
its principal symbol, and caused a good deal of apprehension abroad" (458).

Morrison, in addition, tackles the idea of how white eugenics practitioners preyed on African American women within a national scheme of racist medical experimentation. Medical racism of that period theorized that the white American race should be preserved by the sterilization of other inferior colored races and people with feeblemindedness. Gregory Michael Dorr writes in Segregation's Science” American Eugenics Movement and Virginia 1900-1989 that a number of eugenics scientists of the 1950s, among whom Paul Barringer is the most, adopted a "degeneration theory," that mainly claimed that the African race is hereditably inferior to the white race:

Degeneration, while applying to all humans, also had a racial component, assuming that the different races "declined to different degrees, whites least and blacks most."27 The Virginia eugenicistsparticularly Paul Barringer, Harvey Jordan, Robert Bean, and Lawrence Royster-all built on degeneration theory and eugenics as they constructed theories of racial medicine (660).

As a consequence, legislated and systematic practice of the sterilization of black women was widespread in America from the beginning of the century until the mid 1970s. Michelle Oberman writes that the eugenics movement was "disproportionally concerned with regulating the reproductive lives of women of

(Ripping the Scab off in the Authorial ...)Dr. Ahmed AL-Kahky 
color" (375). Furthermore, Oberman refers to the fact that this "state sponsored" (367) sterilization movement could not be implemented unless for the work of physicians who compromised their "ethical obligation to their patients in the name of carrying out a state policy abound" (368). According to the ideological underpinning of this racist medical experimentation the inferior race of Afro-Americans was the main target of eugenics practitioners. Dorr writes:

Since blacks were believed to be disproportionately criminal, diseased, and hereditarily unfit, the state would realize immediate (and disproportionate) savings if it sterilized blacks. On the more sinister side, sterilizing blacks would increase the dysgenic pressure on the race-maybe the final solution of extinction could be achieved, reasoned some Virginians. Moreover, sterilized black women would be "safe" domestic employees. They could not be impregnated by their employers (631).

Frank's sister Cee, or Ycidra, in Home is a victim of such racist medical experimentation. Cee is stealthily anaesthetized by her employer Dr. Beau who surgically sterilizes her and leaves her unconsciously bleeding to death. Stereotypically, Cee is black, poor and uneducated. She is forced by circumstance to earn her living by working as cleaning woman at Dr. Beau's office. Standing for the first time before her employer, he "seemed pleased" when Cee told him that "had been married for a spell, but had not gotten pregnant" (Home 64).

(Ripping the Scab off in the Authorial ...)Dr. Ahmed AL-Kahky 
Psychoanalytically, Frank's relationship to his sister assumes pivotal importance in the narrative discourse of Home. In spite of his hatred of his little hometown Lotus and his determination never to return to it after he had lost his two best friends in war, Frank is driven by his brotherly obligation towards his sister to come back to it. In fact, Frank's homecoming journey to rescue his sister is a homecoming journey to resuscitate his inner strength. Frank says, "Down deep inside her lived my secret picture of myself - a strong good me tied to the memory of those horses and the burial of a stranger" (Home 104). Ever since their early childhood, with their parents working in the fields from "before sunrise until dark," Frank and his sister Cee have developed the psychological bond of the defenseless little sister and the defender older brother against any evil that may come their way especially from their domineeringly vicious step grandmother Miss Lenore. Their grandfather Salem was always silent about Lenore's abuse of his grandchildren because:

$[\mathrm{H}] \mathrm{e}$ was scared Miss Lenore would leave him the way his first two wives did. Lenore, who had collected a five-hundred-dollar life-insurance payment upon her first husband's death, was a serious catch for an old, unemployed man. Besides, she had a Ford and her house. She was so valuable to Salem Money he never made a sound when the salt pork was halved for the two of them and all the children got was it flavor letting some homeless relatives live in their house after the family got run out of Texas (Home 44).

(Ripping the Scab off in the Authorial ...)Dr. Ahmed AL-Kahky 
As children, Frank and Cee had to face the hardship of living in a secluded little town without adequate facilities, education or life developing opportunities. Thus, with their parents constantly away and eventually dead, Frank had to take full responsibility of his little sister. Frank says, "She was the first person I ever took responsibility for" (Home 104). This responsibility made him feel in his "little-boy heart" heroic and manly. It was his only meaningful life mission that made him feel safe at home and psychologically balanced. Frank explains his feelings to the implied author of his story, who presumably misrepresents him throughout the narrative discourse, "Cee. Ycidra. My sister. Now my only family. When you write this down, know this: she was a shadow of most of my life, a presence marking its own absence, or maybe mine. Who am I without her-that underfed girl with the sad, waiting eyes?" (Home 103)

Therefore, Frank's defense of his sister is in fact a defense of himself. Cee was abused by her step grandmother both physically and psychologically. Cee was "branded early as unlovable, barely tolerated "gutter child" by Lenore," (129) who hit her and Frank and left "stripes and welts" on their bodies. But they were "cautioned to lie, to say they got them by playing out by the stream where brambles and huckleberry thorns grew" (Home 44). Still, Frank role played the defender of his sister ever since their early childhood until it became his sole meaningful purpose in

(Ripping the Scab off in the Authorial ...)Dr. Ahmed AL-Kahky 
life. So, it was only Frank who "valued" and protected her. Nevertheless, the third person narrative voice in Home wonders if it was really his job, and not hers, to value and protect Cee: "[W]hile his devotion shielded her, it did not strengthen her. Should it have? Why was that his job and not her own?" (Home 129)

The answer to this question comes through Frank Money who is profoundly sensitive about his responsibility towards his little sister as well as his fraternity with his two friends whom he had lost in the Korean War. In fact, Frank's trauma involves his deep feeling of loss: losing his best friends and his feeling of being lost in his homeland. It is noteworthy that these feelings of loss at war and at home are intertwined as Frank says:

The letter said, "she be dead." I dragged Mike to shelter and fought off the birds but he died anyway. I held on to him talked to him for an hour but he died anyway...No more people I didn't save. No more watching people close to me die. No more. And now my sister. No way (Home 103-04).

Frank succeeds in rescuing his sister and bringing her back to their hometown Lotus. Cee is left to the collaborative care of the town's elderly women who give her herbal medicine and motherly care. It is remarkable that Cee's recovery is eventually achieved both physically and psychologically, and she becomes an independent person capable of facing her traumatic past and overcoming it. In fact, Frank and Cee's return to their hometown

(Ripping the Scab off in the Authorial ...)Dr. Ahmed AL-Kahky 
is a return to inner peace and psychological balance as they literally exhume the past and burry it forever. Frank and Cee decide to exhume the body of the lynch victim from its grave in order to give it proper burial. Cee makes a quilt - the first she had ever made in her life while recovering the pain inflicted upon her by her racist employer-and decides to use it as a shroud for the dead body:

The quilt became a shroud of crimson, yellow, and dark navy blue. Together they folded the fabric and knotted its ends....Quickly, they found the sweet bay tree-split down the middle, beheaded, undead - spreading its arms, one to the right, one to the left. There at its base Frank placed the bonefilled quilt that was first a shroud, now a coffin. Cee handed him the shovel. While he dug she watched the rippling stream and the foliage of its opposite bank (Home 143-44).

In fact, the final scene in Home assumes great symbolic importance. Cee's quilt is buried along with remnants of the body of the lynch victim. The brother and sister excavate their painful memories as they excavate the bones of the lynch victim then they bury their load of the traumatic past a tree split open in its middle with two branches spread as if they were arms that symbolizes crucifixion and sacrifice as Jessica McKee explains in Ghosts, Orphans: History, Family and the Law in Toni Morrison's Fiction that "Frank excavates the bones of this murdered man just as he mines his memory" (60).

(Ripping the Scab off in the Authorial ...)Dr. Ahmed AL-Kahky 
It is noteworthy that Frank entombs his past traumatic hurt feelings of humiliated manhood through the corrective reburial of the lynch victim who was brought with his son "roped up" from Alabma by racist white men. The racists made them fight with knives against one another: a vicious game "[t]hey graduated from dogfights. Turned men into dogs" (Home 139).

In Trauma: Explorations in Memory, Cathy Caruth explains that Traumatic experience results in the unconscious and involuntarily "return of the event against the will of the one it inhabits." This unconscious feature of the resistant recurrence of the traumatic memory pertains to the historical nature of the traumatic experience as Caruth further explains, "[i]f PTSD must be understood as a pathological symptom, then it is not so much a symptom of the unconscious, as it is a symptom of history. The traumatized, we might say, carry an impossible history within them, or they become themselves the symptoms of a history that they cannot entirely possess" (5). In this respect, Frank Money and his sister Cee in Morrison's Home are fictional symptoms of the traumatic experience of racism in 1950s America. Morrison's ripping of the "scab off that period" of the 1950s is a fictional triumph as she excavates the historical traumas of the forty thousand Americans who died in the Korean War, the PTSD of the black veterans who fought in a desegregated army and returned to a segregated homeland, McCarthyism, Eugenics racist 
practitioners, and the meanest forms of racial violence. Morrison gives voice to the silenced and the numbed through her dialogic narrative discourse. Thus, while Caruth maintains that the greatest challenge to psychoanalysis dealing with trauma is the "peculiar paradox: that in trauma the greatest confrontation with reality may also occur as an absolute numbing of it," (6) Morrison's narrative discourse evokes this traumatic historical past and motivates its illustration through the dialogic interaction with its fictional symptoms: the PTSD victim Frank Money and his sister Cee.

It is remarkably important how Morrison frees her main character Frank Money by endowing him with a consciously free rhetoric that is not only liberated from her implied authorial voice but also from the white domineering stereotyping discourse that insists on shunning the traumatic history of racism and slavery in America. This free liberal consciousness is in matching with Mikhael Bakhtin's concept of the polyphonic novel which is dialogical in nature. In his Problems of Dostoevsky's Poetics, Bakhtin gives great emphasis to Dostoevsky's application of dialogism by affirming the free independent consciousness of his character(s) that "is given as someone else's consciousness, another consciousness, yet at the same time it is not turned into an object, is not closed, does not become a simple object of the author's consciousness" (7). The characters' freedom of consciousness and their consequent polarity of voices do not mean the violation of the dialogic author's artistic message as

(Ripping the Scab off in the Authorial ...)Dr. Ahmed AL-Kahky 
Bakhtin argues in The Dialogic Imagination; rather, they form a background without which the artistic "prose nuances" of the author "cannot be perceived, and without which they 'do not sound" (278). In alignment with this dialogic principle, Morrison enables her main character's independent personal narrative to be placed along with her implied authorial discourse as well as the authoritative discourse of the national history that had for long ignored facts of the 1950s, especially those of the Korean War. In Authenticity in the Fictional Voices of Toni Morrison's Love and Home: Tracing Conversations Among Author, Reader, and Narrators as a Rewrite of U.S. History Maisol Bulacio-Watier writes:

Frank does not particularly perceive himself as a thoughtless experimental object, his first-person narrative is filled with too big of an agency to account for that, but he is aware of, and suffers through, the limitations imposed on his race and social status. And it is precisely this awareness about the realities of the fifties, as opposed to the broadcasted "Leave it to Beaver" sentiment - that is, the iconic and idealized American family representation-which allows him to save his sister's life and gain control over his subjectivity through the narrative. His character and storytelling is a direct challenge to the state's romantic versions of Americaness, as well as a rewrite of U.S. history. (49)

The mechanism of questioning the authoritative discourse through the questioning of the authorial voice pertains mainly to

(Ripping the Scab off in the Authorial ...)Dr. Ahmed AL-Kahky 
the meta-fictional relationship between Morrison and her main character Frank Money. Though the third person narrative voice should not be attributed to the author, it is right to assume this attribution in Home as Morrison admits it in her interview with Lisa Shea, "that was my great discovery!" Morrison explains, "I didn't want to take on the 'I' persona, so he and I are in this relationship. He learns about what he does. He learns about himself" (Interview with Shea). Morrison, likewise, emphasizes this fact in her interview with Torrence Boone as she says, "I liked talking to him. You know, when he was talking to me, and telling me to shut up, that, I didn't know what I was talking about" (n.p.) Thus, Frank is given free independent voice that questions the author's narrative and judges its accuracy and objects to its inability to fill in the gaps in its storytelling. Frank is capable of alternating between the roles of the protagonist, the narrator and the reader of the third person's narrative discourse. Consequently, the main protagonist is not a finalized entity, and the ultimate truth does not pertain to the omniscient narrator.

The most remarkable instance comes in chapter fourteen when Frank says, "I have to say something to you right now. I have to tell the whole truth. I lied to you and I lied to me. I hid it from you because I hid it from me". Frank's most traumatic memory is that of his killing a little Korean girl who came scavenging for food remnants in the camp's garbage dump. In the first person narrative voice, Frank recounts the incident of the

(Ripping the Scab off in the Authorial ...)Dr. Ahmed AL-Kahky 
killing while relating in his subconscious between the little girl, his sister Cee and himself. So he says that she comes crawling on her knees and probing with her "fingers just stretched, patting, searching for something, anything, to eat." And with a "tiny starfish left-handed, like [his]" this girl reminds Frank of himself and his sister crawling under Miss Robinson's tree “trying to steal peaches... sneaking, crawling, being as quite as we could so she wouldn't see us and grab a belt" (Home 94). Still, Frank involves subconsciously in a state of psychological denial of his crime so he projects its guilt onto an imaginary relief guard:

My relief guard comes over, sees her hand and shakes his head smiling. As he approaches her she raises up and in what looks like a hurried, even automatic, gesture she says something in Korean. Sounds like "Yum-Yum." She smiles, reaches for the soldier's crotch, touches it. It surprises him. YumYum? As soon as I look away from her hand to her face, see the two missing teeth, the fall of black hair above her eager eyes, he blows her away. Only the hand remains in the trash, clutching its treasure, a spotted, rotting orange (Home 95).

Nevertheless, Frank shifts his projection of guilt onto the girl's parents who sold her off as a sex slave for food. Amazingly, he describes how loathed his colleague must have been when he shot the girl dead, "Parents threw themselves in from of their kids without a pause. Still, I knew there were a few corrupt ones who 
were not content with the usual girls for sale and took to marketing children" (Home 95-96).

From the perspective of Psychoanalysis, projection is a defense mechanism that is opted for when a subject attempts to reduce the painful effect of his dissonant subconsciousness. Dissonance pertains mainly to the turbulent contending cognitions of one's self-esteem and uncontrollable oppressive relations, attributes or behaviors. Accordingly, Frank Money suffers from the inner struggle between his dissonant ego and super-ego: his self-esteem as a man capable of defending and protecting his little sister and his involuntarily sexual arousal by a little girl who subconsciously reminds him of her. Consequently, Frank tends to project his negative feelings of oppression, hatred, and subjugation onto an imaginary colleague as a means of defense mechanism.

It is noteworthy, that Frank's character is not finalized within the narrative discourse of Home. He is given free independent consciousness and a narrative voice capable of questioning both the authorial and authoritative narrative discourses of his story. So, the reader does not owe the absolute truth of Frank Money's experience to the authorial voice that is beguiled and questioned. In this sense, Morrison eliminates the objectivity of the authorial voice altogether when she presents it as the voice of a subjective writer who omits and misrepresents information. This befits in Bakhtin's concept of the dialogic

(Ripping the Scab off in the Authorial ...)Dr. Ahmed AL-Kahky 
subjectivity of the fictional characters in Problems of Dostoevsky's Poetics, as he explains that the dialogic narrative discourse tends to "affirm someone else's 'I' not as an object but as another subject" (7).

As a free independent subject, Frank suffers from the painful pugnacious shame for killing the little Korean girl and he hides its truth from the narrative discourse until he overcomes his traumatized feelings. The key explanative words of Frank's recovery are uttered when he becomes finally able to admit his guilt. So he says, "I lied to you and I lied to me. I hid it from you because I hid it from me" (Home 133). Needless to say that Frank's concealment of the truth is caused by his deep feeling of shame, which he tries to cover by attributing his grief for the loss of his two colleagues. So Frank says, "I felt so proud grieving over my dead friends. How I loved them. How much I cared about them, missed them. My mourning was so thick it completely covered my shame" (Home 133). The transformation in Frank's character takes place when he and his sister return to their home town. There, Cee is given care by the local women who enable her to recover from her trauma both psychologically and physically:

Cee was not the girl who trembled at the slightest touch of the real and vicious world. Nor was she the not-even-fifteen-year-old who would run off with the first boy who asked her. She was not the household help who believed whatever happened to

(Ripping the Scab off in the Authorial ...)Dr. Ahmed AL-Kahky 
her while drugged was a good idea, good because a white coat said so. (Home 128)

In fact, Cee's recovery motivates Frank's overcoming of his post traumatic disorder. In both cases, the traumatized subject recovers as he/she reaches what Leah Hadomi labels "intopia" in From Technological Dystopia to Intopia: Brave New World and Homo Faber. According to Hadomi, "intopia" is a state of inner reconcilement that a protagonist achieves as he/she becomes motivated by a "utopian drive toward fulfillment of his or her inner self by viewing others, society, and nature through alternative perspectives. The inner quest toward better utopian self is described as the protagonist's striving to understand both oneself and other, and one's commitment to society" (110). Similarly, Mark A. Tabone comments in Dystopia, Utopia and "Home" in Toni Morrison's Home that Morrison's "concrete utopianism is firmly grounded "down here," in part by virtue of her work's tendency to confront, and attempt to overcome, the violence of history" (293). The hopeful ending of Frank's return to home is essentially related to Morrison's concept of home not as a physical space but as spiritual equilibrium that takes place within the protagonists Frank and Cee. Tabone explains that Morrison's narrative of both siblings' trauma is basically an exploration of their curative and recovering return to their sense of belonging to a home at the novel's ending. This is eventually

(Ripping the Scab off in the Authorial ...)Dr. Ahmed AL-Kahky 
achieved by the love and care of the local women who help Cee recover. They relocate their quilting circle to Miss Ethel's house. After the habit of the local women Cee takes to quilting, which is a symbolic act of regaining and rebuilding her devasted being. Cee's return to home transforms her symbolically. Thus, according to Hadomi, home becomes for Cee:

[A] space of care and healing, the community not only stewards Cee's recovery. It transforms her. Symbolically adopting the ethos of her new community, Cee takes up quilting herself. She at last can tell Miss Ethel, "this is where I belong" (126), and her arrival at "home" provides the novel's strongest expression of utopian hope (301).

Thus, Frank Money's odyssean homecoming passes through the stages of forced displacement in childhood, a constant feeling of homelessness, the forced return to the hometown and Cee's eventual psychological and physical healing. It is noteworthy that Frank's healing only takes place when his "gutted" sister "could know that truth, [and] accept it." Frank then tries to "sort out what else was troubling him and what to do about it" (132). The crucial transformation occurs when Frank recognizes his sister's newly gained inner strength so he decides to face his guilt and finally to admit it:

I shot the Korean girl in her face.

I am the one she touched.

I am the one who saw her smile.

I am the one she said "Yum-yum" to.

(Ripping the Scab off in the Authorial ...)Dr. Ahmed AL-Kahky 
I am the one she aroused.

A child. A wee little girl.

I didn't think. I didn't have to.

Better she should die. (Home 133-34).

Thus, the little Korean girl took Frank "to a place [he] didn't know was in [him]," and this led his psychological imbalance and a sense of displacement. The killing of the Korean girl shuttered his feeling of manliness, his most cherished cognition of himself. Frank keeps missing his way home and his estrangement lasts until he eventually becomes able to face the truth of his traumatic history by admitting its occurrence, rather than shunning its facts and falsifying them. This resonates with Cathy Caruth's explanation of trauma, in Trauma: Explorations in Memory, as "a repeated suffering of the event, but also a continual leaving of its site." Caruth, in addition writes that the only possible healing of the trauma comes through listening to "the crisis of a trauma, that is, is not only to listen to the event, but to hear in the testimony the survivor's departure from it; the challenge of the therapeutic listener, in other words, is how to listen to departure." The narrative discourse in Toni Morrison's Home allows its reader to assume that role of the "therapeutic listener" of Frank Money's testimony of the truth of his traumatic experience as well as of the collective traumatic experiences of black men and women in 1950s America. This narrative endeavor requires the annulment of the omniscient capacity of the authorial and the authoritative

(Ripping the Scab off in the Authorial ...)Dr. Ahmed AL-Kahky 
voices all together by means of questioning the credibility of their narrative. Frank's homecoming journey concludes with his coming to terms with his traumatic past by bringing its inherent recurrence in him to an end. This termination of the recurrence of the traumatic memory is essential for the extermination of the power of trauma as Caruth explains:

The historical power of the trauma is not just that the experience is repeated after its forgetting, but that it is only in and through its inherent forgetting that it is first experienced at all. And it is this inherent latency of the event that paradoxically explains the peculiar, temporal structure, the belatedness, of historical experience: since the traumatic event is not experienced as it occurs, it is fully evident only in connection with another place, and in another time. (8)

Toni Morrison succeeds in ripping "the scab off" the of $1950 \mathrm{~s}$ America by allowing access to its hidden and silenced traumatic history. The narrative discourse in Home is a dialogic polyphony of narrative voices which is not dominated by any authoritative or authorial monologic ideology. Toni Morrison succeeds in liberating her main character Frank Money by endowing him with a variant free voice that is "treated as ideologically authoritative and independent...perceived as the author of a fully weighted ideological conception of his own," as Bakhtin writes in Problems of Dostoevsky's Poetics. Accordingly, the character in this dialogic paradigm is not "an object of authorial discourse, but

(Ripping the Scab off in the Authorial ...)Dr. Ahmed AL-Kahky 
rather a fully valid, autonomous carrier of his own individual word" (5).

Home, therefore, is not a monologic creation in which the main character is portrayed as a finalized image of reality according to the author's ideology. On the contrary, Frank Money has neither finalized personality nor subordinate ideology. $\mathrm{He}$ is a free thinking character capable of ideological change and development independent from ideological stance of his fictional creator due to his discursive power which allows him question the dominant narrative of America's national history and expose some of its hidden facts. Thus, as Bakhtin explains in The Dialogic Imagination that in this dialogic creation, "discourse about the world merges with confessional discourse about oneself'. Similarly, Frank Money's confession of his traumatic guilt is intertwined with America's dominant narrative of its history questioning it and revealing its facts. This fits in Bakhtin's theorization that "discourse about the world merges with confessional discourse about oneself. The truth about the world...is inseparable from the truth of the personality" (78).

Eventually, the truth of the 1950s America is revealed through the dialogically discursive power of the narrative discourse in Toni Morrison's Home. Frank Money’s homecoming journey is successful in terms of his being empowered with the capacity to narrate his own story from an independent ideological narrative stance. Consequently, Frank's narrative fills the

(Ripping the Scab off in the Authorial ...)Dr. Ahmed AL-Kahky 
intentionally-left gaps in the America's national history, redefines the historical facts of the time of war and ratifies America's romanticized version of racial tolerance. Thus, Morrison "rewrites the 1950s" as Erin Penner posits, "Her illustration of the uninterrupted march of warfare in the twentieth century defies American regard for the $1950 \mathrm{~s}$ as a period of peace and prosperity" (343). Finally, Toni Morrison is a dialogic author who blatantly believes in creating free independent fictional ideologies to be held by her characters that question and ratify her own ideological stance. The questioning of the hegemonic authorial and authoritative narrative discourses in Home proves that the absence of dialogue has long falsified the truth of U.S. history, while the presentation of a polyphonic dialogue of its variant voices reveals it.

(Ripping the Scab off in the Authorial ...)Dr. Ahmed AL-Kahky 


\section{Works Cited}

Bakhtin, Mikhail. The Dialogic Imagination: Four Essays. Trans. Caryl Emerson and Michael Holquist, Ed. Michael Holquist. $14^{\text {th }}$ ed. Austin: Texas UP, 1981.

---. Problems of Dostoevsky's Poetics. Trans. And Ed. Caryl Emerson. $9^{\text {th }}$ ed. Minnesota: Minnesota UP, 1984.

Brockes, Emma. "Toni Morrison: I Want to Feel What I Feel. Even If It's Not Happiness." The Guardian. Interview. April 13 (2012).

[https://www.theguardian.com/books/2012/apr/13/toni-morrisonhome-son-love]

Caruth, Cathy. Trauma: Explorations in Memory. Ed. Cathy Caruth. London: The John Hopkins Press, 1995.

Dorr, Greogory Michael Segregation's Science: The American Eugenics Movment and Virginia 1900-1980. Thesis. University of Virginia. (2015).

Hadomi, Leah. "From Technological Dystopia to Intopia: Brave New World and Homo Faber." Utopian Studies III. Ed. Michael S. Cummings and Nicholas D. Smith (Lanham, MD: University Press of America, 1991), 110-17.

Hembree, Blayze."Home by Toni Morrison." World Literarture Today. Book Reviews. November 2012

Lerner, Max. America as a Civilization. New York: Henry Holt and Company, 1987.

Mcalpin, Heller"'Home': Toni Morrison's Taut, Triumphant New Novel"

(Ripping the Scab off in the Authorial ...)Dr. Ahmed AL-Kahky 
McKee, Jessica. Ghosts, Orphans, and Outlaws: History, Family, and the Law in Toni Morrison's Fiction. Thesis. University of South Florida, (February 24, 2014)

Morrison, Toni. Playing in the Dark: Whiteness and the Literary Imagination. New York: Vintage Books, 1992.

---. Home. London: Vintage, 2012.

---. "Toni Morrison Home: In Conversation with Torrence Boone." By Torrence Boone.

YouTube.Talks at Google.27 Feb.2013.Web. 15Nov.2018

Montgomery, Maxine L. "Re-Membering the Forgotten War: Memory, History, and the Body in Toni Morrison's "Home." CLA Journal, Vol.55, No. 4 (JUNE 2012), pp. 320-334.

[hhtp://www.jstor.rog/stable/44395688]

Moskos, Jr Charles C. "The American Dilemma in Uniform: Race in the Armed Forces."

The Annals of the American Academy of Political and Social Science, Vol. 406, The Military and American Society (Mar., 1973), pp. 94-106 [https://www.jstor.org/stable/1039666]

Noudelmann, Francois. “An Interview with Toni Morrison." Black

Renaissance; New York Vol. 12, Iss. 1, (Fall 2012): 36-43,151.

Oberman, Michelle. Thirteen Ways of Looking at Buck V. Bell: Thoughts Occasioned by Paul Lombardo. Journal of Legal Education, Vol. 59, No. 3 (February 2010), pp. 357-392.

[https://www.jstor.org/stable/42894126]

Penner, Erin. For Those "Who Could Not Bear to Look Directly at the Slaughter": Morrison's Home and the Novels of Faulkner and Woolf. African American Review 49.4 (Winter 2016): 343-359 [https $/ /$ muse.jhu.edu/article/642823/pdf] (Ripping the Scab off in the Authorial ...)Dr. Ahmed AL-Kahky 
Pordzik, Ralph. "Nationalism, Cross-Culturalism, and Utopian Vision in South African Utopian and Dystopian Writing 1972-92" Research in African Literatures Vol. 32, No. 3, Nationalism (Autumn, 2001), pp. 177-197.

[https $/ /$ www.jstor.org/stable/3820431]

Shea, Lisa. "Toni Morrison on Home." Elle (June15, 2012)

[https://www.elle.com/culture/books/interviews/a14216/toni-morrisonon- home-655249/]

Tabone, Mark A. "Dystopia, Utopia and "Home" in Toni Morrison's Home”. Utopian Studies Vol. 29, No. 3 (2018), pp. 291-308 [https:/www.jstor.org/stable/10.5325/utopianstudies.29.3.0291] Watier, Maisol Bulacio. Authenticity in the Fictional Voices of Toni Morrison's Love and Home: Tracing Conversations Among Author, Reader, and Narrators as a Rewrite of U.S. History. Thesis, Florida Atlantic University. (2017).

Woolf, Virginia. Mrs. Dallawy. Toronto: Clarke, Irwin\& Co. 1950. 